\title{
Leading organizational and economic models for the development of inbound medical tourism in Russia
}

\author{
Olga Nikitina \\ Faculty of Service, Tourism and Hospitality \\ Saint Petersburg State University of Economics \\ Sadovaya street, 21, 191023 Saint Petersburg \\ Russian Federation \\ e-mail: maol@rambler.ru \\ Wadim Strielkowski \\ Prague Institute for Qualification Enhancement \\ Trnkovo náměstí 1112/2, 152 00, Prague \\ Czech Republic \\ e-mail: strielkowski@prizk.cz
}

\begin{abstract}
The paper is based on vast research of primary and secondary foreign and Russian scientific materials, qualitative interviews with foreign and home experts on the development of international medical tourism, as well as the analysis of the peculiarities of its development in Russia. Medical tourism represents one of the leading and most promises fields of tourism nowadays, so it is appropriate to call it a "leader" of tourism industry.

The purpose of this research is to provide a comprehensive overview of current leading trends in medical tourism, mechanisms and models for the implementation of this type of activity, with an analytical focus on the situation in Russia.

This paper examines the main organizational and economic models of the development of international medical tourism. Our research contributes to the development of effective mechanisms for carrying out organized and synchronized activities of all the parties involved, including stakeholders who arrange inbound medical tours, and promote Russia as a new major leading international destination for medical tourists from around the world.
\end{abstract}

\section{Introduction}

Tourism constitutes one of the most rapidly growing and most profitable spheres of economy. With many new fields of tourism such as heritage tourism, film and literature tourism, food tourism, or for example dark tourism (see Strielkowski et al. 2012; Chiabai et al. 2014; Vasylchak and Halachenko 2016; Strielkowski 2017; Abrhám and Wang 2017; Radovic et al. 2017; Romanova et al. 2017; or Strielkowski 2018) on the rise, it is fostered by the easiness and affordability of travel and crossing national borders without visas or with minimal bureaucratic complications, efforts and burdens. However, it is the medical tourism that constitutes a true phenomenon nowadays.

Medical tourism is in high demand in many countries of the world. It is also a highly competitive and lucrative economic activity (see McReady 2007; Chee 2007; Gupta 2008; Gan and Oviedo 2012, 2013; Sarantopoulos et al. 2014; Han and Hyun 2015; Bordea et al. 2017; Mishenin et al. 2018; or Tham 2018).

According to special literature and judging by the results of Internet search queries, the most popular medical tourist destinations include Germany, Austria, Switzerland and Hungary (in Europe), the USA, Argentina, Brazil, Columbia, Costa-Rica, Cuba, Mexico and Jamaica (in America), India, Israel, Malaysia, the Philippines, Thailand and Jordan (in Asia and Pacific) and South Africa and Tunisia (in Africa).

In addition, there is an increasing number of countries around the world which have adapted their healthcare systems to the demands of international medical tourists in order to attract them. Therefore, one can speak about destination countries with a developing medical tourism market. Examples of these countries specializing in medical tourism include China, Latvia, Lithuania, UAE, Poland, Singapore, South Korea as well as many other (see Connell 2006; Gahlinger 2008; Yu et al. 2011; Rodrigues et al. 2017; Choi et al. 2018; or Lee et al. 2018).

Diversification of services in the field of international medical tourism allows specialists to target segments of medical tourism more clearly and precisely in accordance with the special requirements of tourists. For example, today one can identify such areas as check-up tourism (Ruhet 2012), dental tourism (Turner 2008), cosmetic surgical or cosmetic plastic surgery tourism (Franzblau and Chung 2013), and even transplant tourism (Broumand and Saidi 2017; Canales 2006). 
It can be accounted for by the fact that in the majority of countries around the globe, many complex diagnostic research, dental care and plastic surgery are not covered by medical insurance programs, thence these services comprise the biggest part of the growing medical tourist market.

\section{Research methodology and problem statement}

This paper is based on research material which was collected and systematized by the author and covers special literature review and quality interviews with foreign and Russian experts in the area under analysis. The literature review provides a comprehensive analysis of the current scientific and practical information about medical tourism, its perspectives and areas of research in the sphere of medical tourism.

The opportunities of exporting medical services to broad categories of foreign customers have been widely discussed in Russia for a long time, yet there is no unified approach and no direct answer about how to include the Russian tourist resources into the world market of medical tourism.

The analysis of the potential of Russia in the sphere of medical tourism shows there are important statefunded and private medical centers which specialize in a variety of clinical services including diagnosis, therapy and surgery, as well as resort and rehabilitation facilities and recreation centers which provide their patients with convalescent and medical prevention care.

Though there is a high demand for such services among foreign tourists, Russia has not developed any effective mechanisms of organizing inbound medical tourism. This activity is spontaneous and random at times. It is devoid of any conceptual core and synchronized support either from the government or from the community of professionals (tourist, hospitality, insurance and transportation companies). For this reason, many clinics, medical centers and sanatoriums, despite their significant potential and demand for their services, have to withdraw themselves from this sphere as they are not ready to undertake a full cycle of organizational issues to provide inbound medical tours for foreign customers.

In our opinion, the models of development of medical tourism covered in this article will help develop mechanisms of synchronizing efforts of all stakeholders (clinics, tourist agencies, hotels, insurance and transportation companies) involved in the provision of inbound medical tours and promotion of Russia as a new major medical tourist destination in the world market.

\section{Results and discussion}

\subsection{Models of development of medical tourism: international practices}

Medical tourist destinations actively compete with each other in their struggle for each medical tourist. They offer attractive prices, comfortable accommodation, assure the quality of medical services and create effective communication and facilitation channels with medical tourists. The development of medical tourism around the world generates a lot of various medical mediators and coordinators between international patients and medical facilities.

According to Global Buyers' Survey (2016-2017), almost 38\% of medical tourists seek the help of facilitating companies, $16,4 \%$ go to insurance companies, $13,1 \%$ go to tourist agencies, $13 \%$ address insurance agents, brokers and consultants, and 3,3\% ask their doctors for help (GHR2017).

When it comes to medical tourism, a Facilitator 's Handbook (Todd 2012) offers a broad list of medical tourism mediators. They fall into more than 25 categories and subcategories, each has its own profile and a brief description. Medical mediators in destination countries today provide full-cycle services starting from clinic selection, reception, treatment of a patient (there can be a personal manager and an interpreter, available 24/7), to the estimation of treatment results, arrangement of "second opinion" procedures, and general evaluation of the services rendered (quality of treatment, customer satisfaction, staff rating, medical tourists' requirements and suggestions).

"Medical tourism facilitators: Patterns of service differentiation» (Gan and Frederick 2011) describes the biggest players of the medical tourism market by the example of the USA:

- domestic medical tourism facilitators (DMTF),

- foreign medical tourism facilitators (FMTF),

- domestic healthcare providers (DHP),

- foreign healthcare providers (FHP),

- domestic insurance companies (DIC),

- foreign insurance companies (FIC),

- domestic employers (DE). 
Currently, the majority of experts in the sphere of medical tourism single out four models of its development which involve the types of mediators, listed above.

Model 1. Direct medical tourism. In terms of evolution, it is the earliest model of development of medical tourism. It implies direct contacts between a patient and a foreign healthcare provider (FHP).

Model 2. Medical tourism organized by domestic and foreign medical facilitators (DMTF, FMTF). In this case, medical tourists seek the help of special tourist agencies which specialize in searching for suitable foreign clinics and can provide a full package medical tour including treatment, transportation, booking, rehabilitation and convalescent care after a surgery. This model is widespread in such destinations as Israel, India, Latvia, China, Poland, South Korea and other countries.

Model 3. Medical tourism as part of the state healthcare policy. Within this model, foreign healthcare providers (FHP) become plenipotentiary providers of medical services both for individual patients and for state and private domestic employers (DE). This model is aimed at the reduction of healthcare costs. The USA was the first country to implement this model. Now it is widely used in such countries as Canada, Great Britain and some other countries in Europe. Domestic and foreign insurance companies (DIC, FIC) take an active part in the implementation of this policy through forming partnership relations with foreign healthcare providers (FHP). For example, this mechanism is widely used in Switzerland. The country can boast a unique healthcare system with compulsory health insurance for the citizens of the country and its residents, if they have been living in Switzerland for more than three months. According to Swiss law, employers must pay for quality medical care for their employees. That is why many Swiss insurance companies and healthcare foundations develop partnership relations with clinics located in other European countries, for example, in Hungary, Lithuania, Poland and the Czech Republic where medical care is cheaper (Ackermann-Liebrich et al. 2007; Esgroup 2018; GDI 2007). The decision about whether a foreign clinic can be included into the insurance program of medical tourism is based on an accreditation certificate issued by an insurance company (for example, consider the experience of the insurance company Swiss Health).

In July 2018, Israel enacted a law about inbound medical tourism which is a set of regulations and requirements that control the interrelations between the state healthcare system, the private medical sector and Israeli medical facilitators which specialize in providing medical services to overseas patients (IMTA 2018).

In addition, most foreign clinics which participate in medical tourism programs undergo accreditation and receive international certificates which confirm the quality of their medical services. One of the most prestigious and objective certificates that provide medical centers with the right to take part in international tourism programs is provided by the Joint Commission International (JCI), based in the United States. Clinics in Poland, Hungary, Lithuania, Latvia, South Korea, the United Arab Emirates and others use this mechanism to include their medical facilities in the international medical tourism system.

Saudi Arabia has adopted this mechanism to develop inbound medical tourism. Therefore, in the Kingdom of Saudi Arabia, all hospitals which accept foreign patients are accredited by the JCI (Khan and Alam 2014).

Model 4. Medical tourism based on the partnership between DHP, domestic healthcare providers (clinics, diagnostic centers, doctors), with foreign hospitals, medical centers and private medical practitioners (FHP). Within such partnership, national clinics outsource medical services to foreign clinics, but they share "treatment protocols" with foreign partners, provide professional consulting via telemedicine, and organize training of specialists from foreign medical partner clinics. This model today is widely used in the United States and Germany and has serious prospects of development in other countries.

The models described above should be considered as possible directions for the formation of a systemic approach in the development of both inbound and national medical tourism. It might be of great use for those countries where medical tourism is still in its infancy, Russia being one of them.

\subsection{Medical tourism in Russia}

According to the Russian Medical Tourism Association, since 2016 Russia has been witnessing an increase not only in domestic, but also in inbound medical tourism (Pavlenko et al. 2018). According to the Ministry of Health of the Russian Federation, as of 2016, 66.000 foreign patients used the services of Russian medical institutions, and in 2017 this number exceeded 110.000. 74\% of financial income from the export of medical services was earned by providing medical care in hospitals (Nedyuk 2017; Skvortsova 2018; RAOMT 2018).

It is noteworthy that in Russia the development of inbound medical tourism is primarily influenced by such factors as "diaspora", "a high degree of trust in "native" medicine (homeland medicine)" and "absence of the language barrier", because the influx of foreign medical tourists is mostly formed by immigrants from the former Soviet republics, their offspring retaining kinship and language (Muth 2017). They account for about $60 \%$ of the incoming flow of medical tourists. 15.2\% of urban residents from the CIS countries, primarily from Uzbekistan, Turkmenistan, Kirghizia, Kazakhstan, Armenia and Belarus come to Russia for treatment on a visa-free basis. There is a small flow of medical tourists from the countries of the former socialist countries; about $8 \%$ of tourists come with medical purposes from Latvia, Bulgaria, and the Czech Republic. 
Another important factor that stimulates the growth of inbound medical tourism is the significant difference in the exchange rate between the Russian ruble and world currencies due to the imposed international economic sanctions against Russia, which contributed to the formation of attractive competitive prices for medical services in Russia in comparison with similar services in other countries. For example, the cost of a full diagnostic examination in Germany varies between 1.500-15.000 Euro, in Israel - 4.600-6.000 Euro, in Russia the same service costs 380-1.200 Euro (NTU 2018).

According to the Russian Medical Tourism Association, in 2016 dental care became the most popular service with foreign tourists - about $44 \%$ of patients came to Russia to have their teeth treated (Chesnokova 2016).

Urological and gynecological services requested by $23 \%$ of incoming medical tourists rank second. Foreign tourists from the neighboring countries, Europe and the United Arab Emirates came mainly for IVF (in vitro fertilization) which is obviously caused by high quality and low cost: on average, IVF in Russia is 2.5 times cheaper than in these countries.

The third type of medical services most often requested by overseas patients coming to Russia (17\%) is plastic surgery - various kinds of facelifts and rejuvenation, nose and breast surgery. On average, plastic surgery in Russia turned out to be $13 \%$ cheaper for foreigners. Among overseas patients who come to Russia for plastic surgery, there are citizens from the neighboring post-Soviet states, the United States, Israel and Great Britain.

Orthopedics and traumatology were on the fourth place (11\% of foreigners coming to the country). The patients of this category were mostly interested in replacing the hip and other joints. These complex high-tech surgeries attracted the citizens of the United States, France, Great Britain and the Baltic countries to Russian clinics. The fifth place was shared by cardiovascular surgery (3\% of foreigners were interested in it) and ophthalmology (about $2 \%$ ).

It should be noted that practically in all Russian regions the first model of development referred to as Direct medical tourism remains prevalent.

There also information about the development of the second model for the arrangement of medical tours called "Medical tourism organized by domestic and foreign medical mediators". According to the analytical note "On the state and development of medical tourism in the Russian Federation", prepared by N. Kalmykov (Russian Presidential Academy of National Economy and Public Administration) and E. Lazarev (MEDSI), in Russia there are 49 facilitator companies which provide services for incoming, outgoing and internal medical tourists. There are only 10 facilitators engaged in medical tourism in Russia, 4 out of 10 being located in federal cities ( 3 in Moscow, 1 in St. Petersburg) (Kalmykov and Lazarev 2018).

It is important to note that within this model, private medical clinics, sanatoriums, rehabilitation centers are the most active providers of medical services. Obviously, it can be accounted for by the fact that they have more freedom to choose the priority areas of their development and are not bound by the obligation to provide medical services in the framework of state compulsory medical insurance program.

Moscow and St. Petersburg became the most attractive medical tourist destination cities in Russia. They were visited by 60 and 30\% of incoming medical tourists respectively. For example, medical tourists from Finland, Sweden and Denmark often come to the clinics of St. Petersburg for dental care, injection cosmetology and detox therapy services. Due to territorial proximity and cheaper good-quality services, compared to the country of residence, St. Petersburg becomes an attractive medical destination for tourists from Scandinavia. Approximately $5 \%$ of the entire inbound flow of medical tourists head for Siberia and the Far East. Similarly, due to geographical proximity, these regions mostly attract medical tourists from China, Vietnam and South Korea. They come for dental care and IVF. The remaining regions of Russia account for no more than 5\% (Arkharova 2017).

To balance the inbound tourist flows, it is currently planned to form regional clusters in Russia which will serve as a basis for the development of medical tourism, and by 2024 the number of medical tourists entering Russia is expected to reach 500.000 people a year (Nedyuk 2017).

According to the data of the survey "Medical Tourism Index, 2016" (MTI 2016), Russia ranks $34^{\text {th }}$ in the global ranking of 41 countries in the development of medical tourism infrastructure. Among the European countries, on its $9^{\text {th }}$ place Russia follows the UK, Germany, France, Italy, Spain, Poland, Malta and Turkey. The MTI rating takes into account not only the competence, reputation of doctors and standards of service, but also the attitude of the staff to patients in general and the friendliness of the staff. Interestingly, Russia is so low in the list for two major reasons: first, in Russia there is a clear deficit of qualified medical specialists who could communicate with patients in foreign languages. Secondly, in Russia there is no concept of the so-called "medical visa" which would allow overseas patients to obtain a visa very fast with the help of medical documents and arrange a flexible schedule to visit the clinic (doctor), including repeated visits in case of long-term treatment. Therefore, most medical tourists come to Russia with a tourist visa.

\section{Conclusions}

In order to be able to compete both with the new leaders of international medical tourism (Asia-Pacific region) and the traditional European players in this market, Russia must be actively involved in this sphere, develop the 
infrastructure for inbound and domestic tourism and increase and maintain a specialized pool of medical tourism facilitators. Besides, to develop a systemic approach to the integration of Russian medical centers into the international system of medical tourism and to attract incoming overseas patients, Russia must focus on the most successful models of the development of medical tourism. In particular, Models 3 «Medical tourism as part of the state healthcare policy» and 4 «Medical tourism based on the partnership between domestic healthcare providers with foreign hospitals, medical centers and private medical practitioners (FHP)».

Also, it is necessary to pay special attention to the training of medical personnel who speak foreign languages, to speed up the development of regulatory and legal solutions to resolve visa issues for foreign patients with a view to participate in the international medical tourism program in Russia, to stimulate the work of all facilitators in order to improve the quality of medical services, the introduction of not only international "protocols of treatment", but also service protocols. It is necessary to offer economic benefits to those medical facilities which receive international certificates and thus obtain the right to take part in international medical tourism programs.

\section{Acknowledgments}

The authors are grateful to the administration of the scientific department of the St. Petersburg State Economic University for the financial support of the research in the form of a grant

The authors express their gratitude to the V. Potanin Charity Foundation for the financial support of the research in the form of a grant.

\section{References}

Abrhám J, Wang J (2017) Novel trends on using ICTS in the modern tourism industry. Czech Journal of Social Sciences, Business and Economics 6(1):37-43. doi: 10.24984/cjssbe.2017.6.1.5

Ackermann-Liebrich U, Ludwig C, Darioli R (2007) „Versicherungsmedizin“, in Gutzwiller, F. and Paccaud, F. (ed.), Sozial- und Präventivmedizin, Public Health (3rd complete revised edition), Hans Huber Verlag, Bern, pp. 153-193.

Arkharova I (2017) Medicinskij turizm v Rossii priros bolee chem vdvoe [Medical tourism in Russia has more than doubled]. https://www.tourprom.ru/news/37673/ Accessed 18 July 2018

Bordea E, Manea M, Pelligrini A (2017) Unemployment and coping with stress, anxiety, and depression. Czech Journal of Social Sciences, Business and Economics 6(2):6-14. doi: 10.24984/cjssbe.2017.6.2.1

Broumand B, Saidi RF (2017) New Definition of Transplant Tourism. International Journal of Organ Transplantation Medicine 8(1):49-51.

Canales M. T., Kasiske B. L. and Rosenberg M. E. (2006). Transplant tourism: Outcomes of United States residents who undergo kidney transplantation overseas. Transplantation 82(12):1658-1661. doi: 10.1097/01.tp.0000250763.52186.df

Chee Heng Leng (2007) Medical Tourism in Malaysia: International Movement of Healthcare Consumers and the Commodification of Healthcare (January 1, 2007). Asia Research Institute Working Paper No. 83. doi.org/10.2139/ssrn.1317163

Chesnokova O. (2016) 44\% inostranny`x pacientov edut v Rossiyu lechit`zuby` [44\% of foreign patients go to Russia to treat their teeth] https://vademec.ru/news/2016/12/23/44-inostrannykh-patsientov-edut-vrossiyu-lechit-zuby/ Accessed 18 July 2018

Chiabai A, Platt S, Strielkowski W (2014) Eliciting users' preferences for cultural heritage and tourism-related eservices: a tale of three European cities. Tourism Economics 20(2):263-277. doi: 10.5367/te.2013.0290

Choi WA, Kim H, Lee SC (2018) Word-of-mouth in medical tourism: the major determinant for Emirati patients to visit Korea. The Korean journal of internal medicine 33(1):221. doi:10.3904/kjim.2015.182

Connell J (2006) Medical tourism: Sea, sun, sand and... surgery. Tourism management 27(6):1093-1100. doi.org/10.1016/j.tourman.2005.11.005

Esgroup (2018) The «Brilliant» Named Switzerland. Part 4. Swiss Healthcare and Medical Tourism / ARTICLES. Education standard. https://esgroup.uz/en/articles/90/brillilant-switzerland-part-4

Franzblau L E, Chung K C (2013) Impact of Medical Tourism on Cosmetic Surgery in the United States. Plastic \& Reconstructive Surgery Global Open, 2013; doi 10.1097/GOX.0000000000000003 
Gahlinger, P. (2008), The Medical Tourism Travel Guide: Your Complete Reference to Top-Quality, LowCost Dental, Cosmetic, Medical Care \& Surgery Overseas.North Branch, MN: Sunrise River Pre ss, 322 p.

Gan L.L. and Frederick, J.R. (2011). Medical tourism facilitators: Patterns of service differentiation. Journal of Vacation Marketing, 17(3), 165-183. doi 10.1177/1356766711409181

Gan Lydia L. and Oviedo, Nina, Medical Tourism: A SWOT Analysis of Mexico and the Philippines (March 18, 2013). doi.org/10.2139/ssrn.2234866

Gan Lydia L. and Song Hongwei (2012) A SWOT Analysis of Medical Tourism: India and South Korea (June 27, 2012). doi.org/10.2139/ssrn.2194856

GDI (2007) Gottlieb Duttweiler Institut -“Trendstudie - Die Zukunft der Schweizer Hotellerie”, Studie zum 125-Jahre-Jubila“um von hotelleriesuisse, hotelleriesuisse, Bern. Available at: https://www.hotelleriesuisse.ch/files/pdf4/Trendstudie_GDI_2007.pdf

GHR (2017) GLOBAL BUYERS SURVEY 2016-2017. BRIEF. Global Healthcare Resources. Published in 2017 in partnership with the IHRC and MTA/ Available at: http://medicaltourismassociation.com/userfiles/files/GLOBAL_BUYERS_REPORT_BRIEF.pdf

Gupta AS (2008) Medical tourism in India: winners and losers. Indian Journal of Medical Ethics, 5(1), 4-5. doi: 10.20529/IJME.2008.002

Han H, Hyun SS (2015) Customer retention in the medical tourism industry: Impact of quality, satisfaction, trust, and price reasonableness. Tourism Management, 46, 20-29. doi: 10.1016/j.tourman.2014.06.003

IMTA (2018) Haaretz: Israel Moves to Regulate the Big Business of Medical Tourism. https://imta.co.il/en/news/item/347-haaretz-israel-moves-to-regulate-the-big-business-of-medical-tourism Accessed 15 July 2018

Kalmykov N. and Lazarev E (2018) Analiticheskaya zapiska «O sostoyanii i razvitii medicinskogo turizma v Rossijskoj Federacii» [Analytical note "On the state and development of medical tourism in the Russian Federation"] https://www.ranepa.ru/images/News/2018-03/30-03-2018-3-medturizm.pdf Accessed 27 July 2018

Khan S, Alam MS (2014) Kingdom of Saudi Arabia: A potential destination for medical tourism. Journal of Taibah University Medical Sciences 9(4):257-262. doi:10.1016/j.jtumed.2014.01.007

Lee J, Kim TY, Shin JS, Lee J, Kim HN, Lee YJ, Kim MR, Ahn YJ, Park KB, Kim KH, Suhr K (2018) Korean and conventional medicine tourism industry trends as indicated in medical tourism advertisement images: qualitative research using data from medical Korea 2015. Asia Pacific Journal of Tourism Research 23(7):703713. doi: 10.1080/10941665.2018.1487459

MacReady N (2007) Developing countries court medical tourists. The Lancet 369(9576): 1849-1850. doi: 10.1016/S0140-6736(07)60833-2

Mishenin Y, Koblianska I, Medvid V, Maistrenko Y (2018) Sustainable regional development policy formation: role of industrial ecology and logistics. Entrepreneurship and Sustainability Issues 6(1):329-341. doi: 10.9770/jesi.2018.6.1(20)

MTI (2016) Overview - Medical Tourism Index, 2016. https://www.medicaltourismindex.com Accessed 18 July 2018

Muth S (2017) Russian as a commodity: medical tourism and the healthcare industry in post-Soviet Lithuania. International Journal of Bilingual Education and Bilingualism 20(4):404-416. doi: $10.1080 / 13670050.2015 .1115002$

Nedyuk M (2017) Minzdrav sdelal stavku na razvitie medicinskogo turizma [Ministry of Health has relied on the development of medical tourism]. https://iz.ru/645838/mariia-nediuk/minzdrav-sdelal-stavku-narazvitie-meditcinskogo-turizma Accessed 20 July 2018

NTU (2018) Medical Tourism in Russia. https://rusunion.com/o-razvitii-medicinskogo-turizma-v-rossii/ Accessed 19 July 2018

Pavlenko I, Polishchuk E, Pilyavskiy V, Ushakov D (2018) The Strategy of Thai Medical Services Promotion at Russian Markets. Advanced Science Letters 24(9):6343-6346. doi:10.1166/asl.2018.13049

Radovic D, Strielkowski W, Wang J, Cepel M, Rausser G (2017) Economic analysis of sustainable tourism: a case study of Nottingham. Transformations in Business \& Economics 16(2B):703-714. 
RAOMT (2018) Russian Association of Medical Tourism. https://amtrf.ru/express.html. Accessed 21 July 2018

Rodrigues H, Brochado A, Troilo M, Mohsin A (2017) Mirror, mirror on the wall, who's the fairest of them all? A critical content analysis on medical tourism. Tourism Management Perspectives 24:16-25. doi: 10.1016/j.tmp.2017.07.004

Romanova OA, Korovin GB, Kuzmin EA (2017) Analysis of the Development Prospects for the High-Tech Sector of the Economy in the Context of New Industrialization. Espacios, 38(59):25.

Ruhet Genç (2012) Physical, Psychological, and Social Aspects of QOL Medical Tourism. Handbook of Tourism and Quality-of-Life Research. Springer Science+Business Media B.V., pp 193-207.

Sarantopoulos I, Vicky K, Geitona M (2014) A supply side investigation of medical tourism and ICT use in Greece. Procedia-Social and Behavioral Sciences 148:370-377. doi:10.1016/j.sbspro.2014.07.055

Skvortsova V (2018) Za poslednij god v 4 raza vozroslo chislo inostrancev, priezzhayushhix lechit`sya v Rossiyu [For the last year, the number of foreigners who come to Russia for treatment has increased 4-fold]. https://www.newsru.com/russia/25may2018/medturizm.html Accessed 22 July 2018

Strielkowski W (2017) Promoting Tourism Destination through Film-Induced Tourism: The Case of Japan. Market-Trziste 29(2):193-203. doi:10.22598/mt/2017.29.2.193

Strielkowski W (2018) Heritage, screen and literary tourism. Tourism Management 69:537-537. doi: 10.1016/j.tourman.2018.07.004

Strielkowski W, Riganti P, Wang J (2012) Tourism, cultural heritage and e-services: Using focus groups to assess consumer preferences. Tourismos: an International Multidisciplinary Journal of Tourism 7(1):41-60.

Tham, A. (2018). Sand, surgery and stakeholders: A multi-stakeholder involvement model of domestic medical tourism for Australia's Sunshine Coast. Tourism Management Perspectives, 25, 29-40. doi:10.1016/j.tmp.2017.11.002

Todd Maria K, Medical Tourism. $1^{\text {st }}$ edn. (Facilitator's Handbook, CRC Press, Taylor \& Francis, 2012), 180 .

Turner L (2008) Cross-border dental care:'dental tourism'and patient mobility. British dental journal 204(10):553-554. doi: 10.1038/sj.bdj.2008.403

Vasylchak S, Halachenko A (2016) Theoretical basis for the development of resort services: regional aspect. International Economics Letters 5(2):54-62. doi: 10.24984/iel.2016.5.2.3

Yu J, Lee TJ, Noh H (2011) Characteristics of a medical tourism industry: The case of South Korea. Journal of Travel \& Tourism Marketing 28(8):856-872 doi: 10.1080/10548408.2011.623052 